\title{
MANAGEMENT FOR SUSTAINABILITY
}

\author{
Dror Etzion \\ McGill University \\ dror.etzion@mcgill.ca
}

\begin{abstract}
$\underline{\text { Abstract }}$
Much of the unsustainable activity that occurs in the world can be traced to organizations. Yet, because organizations are social systems, they cannot be managed for sustainability in the same way as ecosystems and natural resources. Using social systems theory, and employing the concepts of emergence, resilience and scale, I identify management principles for pursuing sustainability across an array of organizational contexts. These principles serve as a basis for an agenda to promote sustainability through logic models and experimentation. The UN Sustainable Development Goals provide an opportunity for putting these principles into action.
\end{abstract}

Published in Nature Sustainability 1 (12), 744 
The archetypical organizations in the world - corporations, proprietorships, hospitals, schools, voluntary associations, and others - rarely pursue sustainability as a primary objective, and are often rather indifferent to it, or in some cases even opposed ${ }^{1,2}$. This is unfortunate, because many negative sustainability impacts, as well as opportunities to address them, reside in systems that are at their core organizational. Examples of ways in which some organizations engage with sustainability include a multinational conglomerate that embraces the circular economy as a business opportunity ${ }^{3}$, a university divesting its financial holdings from fossil fuels to undermine the legitimacy of carbon based energy sources ${ }^{4}$, and the Girl Scouts conducting child-centered interventions to promote household energy-saving behaviours enacted by both the Scouts and their parents ${ }^{5}$. Clearly, organizations should be recognized as arenas where varied and meaningful action towards greater sustainability can originate.

To fully comprehend the possibilities and limitations of organizational engagement with sustainability requires a familiarity with management theory, a social science that examines organizations and organizing ${ }^{6}$. It is a "big tent" academic enterprise, informed by psychology, sociology, economics and other disciplines ${ }^{7}$. Consequently, levels of analysis range from the micro - the individual inside the organization - to the macro - the way in which organizations interact with societies ${ }^{8}$. Researchers seek to understand a broad array of phenomena, including decision making routines, innovation processes, forms of inter-organizational collaboration, modes of governance, and gender diversity, to name but a very small number. Notably, these and other organizational phenomena are investigated as both independent and dependent variables, indicating researchers' interest in both their antecedents and their consequences.

From its earliest days, a primary research interest for management theory has been the structures, workflows and practices which promote efficiency and peak performance. In effect, management researchers often emulate engineers, and model organizations after machines to provide guidance for managers on how to design and run organizations so that they perform optimally ${ }^{9}$. Management theory, however, is decidedly pluralistic, as opposed to paradigmatic ${ }^{10}$. Other approaches illuminate characteristics of organizations in a way that the machine model cannot $^{11}$. Many researchers explore organizations as cultures or mini-societies, infused with values, norms and myths that are decidedly human and not mechanistic ${ }^{12}$. Some researchers conceptualize organizations as brains, drawing attention to information processing, decision making, and learning ${ }^{13,14}$. Yet another school of thought studies organizations according to 
principles of ecology. In it, researchers model differences in organizational forms as analogous to speciation, and examine how these species fit in organizational environments, and what factors affect their survival ${ }^{15}$. Another approach equates organizations to political systems. Researchers in this stream explore power, control and interests at individual and group levels ${ }^{16}$.

Common to most perspectives in management theory is their primary focus on the social aspects of organizing. Correspondingly, meager attention is paid to how organizations interact with physical and natural systems. The same is true for many organizations themselves. There are several reasons why both organizations and the researchers who study them often ignore sustainability. First, and most importantly, organizations - be they corporations, not-for-profits, government agencies or others - concurrently pursue multiple, and occasionally conflicting goals, such as organizational survival, financial gain, or some form of social impact.

Sustainability may be one of them, but often it is not ${ }^{17}$. Second, organizations operate at different scales than sustainability challenges. Sustainability concerns are typically long-term and systemic, whereas organizations are generally oriented towards attaining short term, tractable goals such as producing a widget or providing a specific service ${ }^{18}$. Third, organizations tend to be particularly effective in domains where they are knowledgeable and over which they have control $^{19}$, whereas sustainability issues are not neatly bounded ${ }^{20}$, and their complexity precludes full and complete comprehension.

\section{Organizations and wicked problems}

At first glance, this portrayal appears to provide meager traction for orienting organizations toward sustainability in ways that are impactful. If organizations don't understand a problem, have little control over it, and are not geared towards its resolution, how can they help solve it? In the context of natural resource management, theories of adaptive governance ${ }^{21}$ and co-management ${ }^{22}$ were developed to tackle precisely these types of situations. Adaptive management frameworks strive to reduce systemic uncertainties through diagnostic experimentation and hypothesis testing. Results from experiments inform subsequent rounds of policy formation in iterative "Plan-Act-Monitor-Evaluate" ${ }^{23}$ cycles, managed via carefully calibrated and inclusive governance arrangements. And yet, adaptive management implementations encounter obstacles in contexts that are highly uncertain, and particularly those 
enmeshed within social, political and institutional constraints ${ }^{24}$. In other words, when sustainability challenges present as multidimensional, wicked problems.

Much has been written about wicked problems in management theory ${ }^{25}$, natural resource management ${ }^{26}$, and public administration and planning, where the term originated ${ }^{27}$. For social scientists, wicked problems are interesting not merely because they are intractable, but also because they are interpretive. Rittel and Webber, in their seminal article ${ }^{27}$, captured this well, proposing that "the choice of explanation determines the nature of the problem's resolution". The climate crisis, for example, is understood by some to be a moral failure, by others to be a consequence of geopolitical deadlock, and by yet others as a technological hurdle, with each explanation respectively entailing divergent solutions ${ }^{28}$. Similarly, water can be understood contemporaneously as a human right, an economic good and a natural resource. None of these views is categorically incorrect - each conveys a kernel of truth - yet each also delineates a fundamentally different course of action. "Both the existence of a problem situation and its interpretation are human judgments" ${ }^{29}$. Overall, for wicked problems, it is difficult for different actors to agree on the name and attributes of the problem that they are trying to solve, let alone agree on remedies.

Thinking of issues and systems in this "soft" ${ }^{30}$ way suggests that the managerial models we apply for sustainability are not so much objectively true as they are tools for making sense of reality and shaping the way we act. The way we understand problems is not merely descriptive; it delineates the solution space, and provides the language and coordinating mechanisms for addressing them ${ }^{31,32}$. While this depiction might seem to be at odds with the "hard" systems science of natural resource management, there is much to be gained by having the two approaches inform each other, mainly through closer examination of concepts such as emergence, resilience, and scale.

\section{Emergence}

When managing, one's tendency is to impose hierarchy, knowledge and order ${ }^{33}$. In this idealized form of management, highly trained experts amass relevant expertise, and, through analysis, prescribe optimal paths for attaining clearly specified outcomes. An exemplar is the Apollo program, whose goals Kennedy succinctly set forth in 1961: "before this decade is out, of landing a man on the moon and returning him safely to the earth." An organization - the three 
year old NASA - was assigned the task, and set about attaining the goal with best managerial practices, to great effect. The success of the Apollo program makes it a common reference point for sustainability challenges, which seem to require the same level of urgency and resolve.

This managerial approach is the standard model taught in business schools today, for organizational problems large and small. Often forgotten is that this approach can also yield spectacular failure, as evinced by the Space Shuttle program, particularly the horrific loss of Challenger in 1986 and Columbia in 2003, outcomes which suggest that the deliberate, hierarchical model of management can fail even in contexts to which it is ostensibly wellsuited $^{34}$. Similar failings of "command and control" are well documented in the natural resource sciences $^{35}$. More interestingly perhaps, in situ management in organizations is rarely enacted this way. Good managers realize that strategy and planning are not synonymous ${ }^{36}$. Often, they allow strategies to emerge as part and parcel of organizational members' efforts to solve pressing, quotidian problems, rather than through policy directives promulgated by the head office. Emergent strategy embraces bottom-up decision making but is not a synonym; it entails the recognition of patterns and opportunities that become visible in unexpected ways ${ }^{37,38}$. Many actors are involved, anywhere in the organizational hierarchy or outside it, and they do not necessarily follow structured decision making processes ${ }^{39}$.

An instructive example is the emergence of wind turbine technology. The dominant design - slow-moving blades revolving around a horizontal axis - most emphatically did not originate through top down planning and cutting edge engineering expertise ${ }^{40}$. Rather, it evolved in Denmark over several decades beginning in the 1970's, in what can be described as a process of "path creation" 41 . Several tradesmen in the Jutland peninsula, operating independently, began tinkering with a 1950's design that had been developed and later scrapped by a Danish utility. Local farmers installed these small turbines for on-site use, enabling further innovation. As they began to receive positive press coverage and public interest in wind power grew, politicians began framing this novel technology as a way to promote energy independence. A national Test and Research Center was established, and it explicitly prioritized building bridges between existing knowledge communities rather than conducting ivory-tower research. A cluster of firms - including Vestas, Micon and Bonus - enacted a mix of competition, collaboration and risk sharing that led to industry growth. They identified international opportunities, and Danish exports increased dramatically, making the country a global leader in wind energy. This precise 
mix of bottom-up organization, technological bricolage, industry-government collaboration, and managerial recognition of emergent opportunity could never have been predicted, let alone planned. Rather, managers and policymakers identified "building blocks" 42 to success, perceived patterns, possibilities and intentions, and created paths for pursuing them.

\section{Resilience}

In the sustainability sciences, resilience is used to describe the state of a system, and measures its capacity to absorb change without altering fundamental properties ${ }^{43}$. Resilience is often a desirable attribute, supporting the vitality of ecosystems, and their capacity to withstand degradation ${ }^{44}$. And yet, a system will also be resistant to change when in a less desirable state. Collapsed fisheries, degraded coral reefs, and poverty traps are examples. The same is very much true of organizations and other social structures, which can get mired in inertial dynamics that make them unresponsive and uncompetitive - unhelpfully resilient. This is why "change management" is such a difficult organizational endeavor.

To move people and organizations out of undesirable resilient states, typical remedies suggest that explaining the current situation and its shortcomings, articulating a vision for a better one, and providing resources and guidance on how to transition will provide enough of an impetus to create such a shift. Change management processes in organizations proceed along this temporal sequence ${ }^{45}$, highlighting the importance of a compelling vision to orient organizational strategy (e.g. around sustainability ${ }^{46}$ ). These templates are founded upon the "information deficit" model of action, which contends that lack of awareness and knowledge explain why people behave undesirably or illogically ${ }^{47}$. The model predicts that providing people a convincing explanation about the (singular, well-defined) problem will impel them to act to solve it. Yet, in the context of sustainability, it is becoming increasingly clear that resistance to change does not stem from ignorance. Rather, individuals prefer to interpret information and messages in ways that reinforce their cultural predispositions ${ }^{48,49}$. This tendency can keep organizations and individuals mired in a resilient state characterized by inertia and irresponsiveness.

In contrast, acknowledging the interpretive nature of sustainability challenges and wicked problems more generally suggests that there is not $\boldsymbol{a}$ problem, around which to build consensus and momentum. Rather, each of us frames our understanding of issues based on cultural 
underpinnings and value systems, which tend to be stable and resistant to scrutiny. This does not mean that people who are not interested in or aligned with scientific understandings of sustainability are indiscriminately opposed to it. Simply, certain narratives about sustainability do not resonate for them, or inspire them to act. Hence, obtaining support obliquely ${ }^{50}$ can be a more effective approach for enlisting people and organizations to engage with sustainability concerns.

This is the key insight behind the managerial concept of "robust action": the accomplishment of short-term objectives while preserving long-term flexibility ${ }^{51}$. As befits its name, robust action is predicated upon action that is resilient, not systems ${ }^{52}$. Robust action recognizes that interpretations and understandings may differ, but do no not necessarily preclude common objectives. Indeed, a key feature of robust action is multivocality, a form of communication that permits audiences to make sense of meaning in more than one way ${ }^{53}$. Multivocality helps engage a variety of audiences and avoids contestation by not trying to teach, explain or convince. It mobilizes without asserting a coherent, complete worldview. Instead, it provides linguistic anchors and shared goals for individuals to latch on to, according to their distinct needs and values. Often, such an approach yields strange bedfellows characterized by ideological incongruence ${ }^{54}$. Such alliances are found in Midwest American states, whose populations support renewable energy installations because they reduce energy costs and provide employment opportunities, even though the majority of residents in these "red states" do not identify with the climate movement ${ }^{55}$. Similarly, although conservationists and conservatives have worldviews that are ideologically at odds, hunters and fishers, many of whom lean conservative, can find common ground with conservationists on the issues of natural habitat preservation. Placing monetary value on ecosystem services produces a similar result, aligning the actions, but not the beliefs of supporters ${ }^{56}$. In all these contexts, agreeing is not an antecedent to doing. Rather, through interpretative flexibility ${ }^{57}$, individuals and organizations find the fit between avenues for action and their belief systems.

\section{Scale}

Emergence allows many ideas to flower, but local, focused efforts will often be limited in their impact. As such, scaling up is perceived as crucial. A rule of thumb from management theory, however, is that strategies that are particularly effective in a specific context cannot be 
assured of success when replicated elsewhere. In particular, scaling up is hindered when cause and effect relationships are difficult to identify ${ }^{58}$, which is perhaps the defining characteristic of complex systems and wicked problems. Usually, solutions that have proven themselves in a certain location are precisely those that have - through robust action and other forms of iterative learning - conformed to the unique contingencies in which they were conceived ${ }^{59}$. Any attempt to mimic such a solution in a different context inevitably requires adjustments ${ }^{60}$. This means that the exquisitely calibrated "business model" that proved so effective in the original context must necessarily be altered as it expands. Such is the case of microfinance, which was pioneered in Bangladesh, but failed conspicuously when transplanted to India, Bosnia and elsewhere without much modification. In Bolivia, however, where it was re-envisioned, and not replicated in cookie-cutter fashion, microfinance has flourished ${ }^{61}$.

Other efforts to scale emphasize scaling out, or expanding the scope of successful organizations - "diversification" in management-speak. One example is Grameen, which has expanded from its roots as a microfinance organization to the telecom and food sectors, among others, with varying levels of success ${ }^{62}$. Diversification is notoriously difficult for the same reason that replication is: competence in one context is not easily transferable to others, and additional layers of management typically reduce emergence and agility ${ }^{63}$. Not without reason are organizations exhorted to stick to their knitting - their "core competencies" $" 64,65$.

Sustainability contexts may require us to think of scale in other ways, and in particular by identifying leverage points - "places within a complex system (a corporation, an economy, a living body, a city, an ecosystem) where a small shift in one thing can produce big changes in everything" "66. Leverage can be attained by identifying and activating latent pathways between issues typically perceived as unrelated. For example, the non-profit partnership Health in Harmony, working with local non-profit ASRI, used a radical listening approach to understand what impelled rural populations in Indonesia to log critically endangered habitat ${ }^{67}$. They discovered that high medical costs were forcing people to turn to logging to pay for health care, and that conventional agricultural practices were depleting the soil of nutrients, leading to slashand-burn agriculture in the vicinity of natural parks. Consequently, the organizations began to offer low cost health care and training in organic farming, thereby allowing residents to refrain from logging local forests for income. In a nutshell, the Health in Harmony model uses accessible heath care as a mechanism for preserving orangutan habitat. 
In another NGO-led initiative, Gram Vikas works in Indian villages to improve water quality ${ }^{68}$. The organization emphasizes that clean water is attainable only if all community members agree to stop polluting water through open defecation. In fact, Gram Vikas refrains from implementing its program in a village until each and every single household agrees to participate. When agreement is secured, Gram Vikas enforces a formal contract that binds all the village's residents to the program, and requires them to engage in direct dialogue with each other, regardless of class and gender. Meetings to discuss water and sanitation turn into a space for breaking taken-for-granted patterns of interaction. In essence, Gram Vikas strives to erode the caste system and fight inequality through community-wide dialogues about water.

The surprising nature of the linkages between disparate sustainability outcomes in these two examples highlights the key to their success. Such pathways to effectiveness are nearly impossible to plan, require intimate local knowledge, and can most effectively be uncovered through emergence and nurtured through robust action.

\section{Finding leverage}

Managers intent on pursuing sustainability based on an appreciation of robust action and path creation can benefit from suitable tools to support their efforts. One such tool is logic modeling, which has proven effective for developing and evaluating public programs and philanthropic efforts ${ }^{69}$. Logic models are a visualization of a causal chain that describes how specific resources are transformed into activities to produce desired results (see Fig. 1a). Logic models make an important distinction between outputs - the actual deliverables that an organization has control over (e.g. health-care services provided by Health in Harmony, Fig. 1b) - and outcomes - the desirable results that the organization believes that its outputs will promote, at shorter and longer temporal scales (e.g. growth in orangutan populations in the short-term and biodiversity preservation in the long-term, Fig. 1b). Similarly, consider an organization rolling out a technology that provides clean water to households in the global South. The number of liters of clean water provided is an output. The amount of time freed up for women and girls who would otherwise be fetching it is a short-term outcome, and a long-term outcome is likely to be higher levels of female education, and stronger families and communities ${ }^{70}$.

The value of logic models is that they force their designers and evaluators to explicitly identify leverage points: specific outputs that will generate meaningful outcomes. It is precisely 
at that interface where a more meaningful manifestation of scale can be realized, focusing on "expanding impact" rather than "becoming large". Often, organizations look inward to identify opportunities for lowering their negative environmental impacts. Organizations might, in parallel, try to have greater positive impact by looking outward, and thinking rigorously of the outcomes that they are producing. In particular, organizations should explore impact at scale not only via pathways of scaling-up but also by scaling-out, aspiring to be "catalysts of policy innovations and social capital, creators of programmatic knowledge that can be spun off and integrated into government and market institutions, and builders of vibrant and diverse civil societies"71.

Of course, logic models run the risk of oversimplifying cause and effect dynamics of complex adaptive systems. They may not capture the simultaneous efforts of multiple actors in a system and cannot anticipate emergent outcomes. Consequently, guidance for using logic models emphasizes robustness, meaning that they must be iterative and should evolve as organizational environments change and actual outputs and outcomes become available for analysis ${ }^{72}$. Researchers can endeavor to enrich logic models with agent based capacities, in which each agent has a set of rules guiding their behavior, to allow the models to generate outcomes that are difficult to otherwise foresee ${ }^{73}$.

Additionally, researchers can explore the application of logic models at larger scales, even at the level of the United Nation's Sustainable Development Goals. The seventeen SDGs are in effect a set of desired outcomes that equate with global sustainably. The SDGs are systemic, meaning that together, they constitute a network of interconnected issues ${ }^{74,75}$. Table 1 describes several thoughtful initiatives that engage deeply with the complex nature of the SDGs by mapping interlinkages, thereby identifying potential leverage points, while at the same time uncovering trades-offs that may be necessary.

Consider food waste, one wicked problem where interlinkages among the SDGs can be generative. Food waste is explicitly listed under Sustainable Development Goal 12, which focuses on sustainable consumption and production patterns. Under Goal 12, Target 12.3 states, as a desired outcome, to "by 2030, halve per capita global food waste at the retail and consumer levels and reduce food losses along production and supply chains, including post-harvest losses"76. The UN estimates that food waste contributes to $3.5 \mathrm{Gt} \mathrm{CO}_{2} \mathrm{e}$ of greenhouse gas 
emissions per year, and $3 * 10^{11} \mathrm{~m}$ of irrigated water loss ${ }^{77}$. Reducing food waste will therefore contribute to combating climate change (Goal 13) and attaining water availability for all (Goal 6). Through additional linkages in the food-water-energy nexus ${ }^{78}$, reducing food waste will also help ensure healthy lives and promote well-being (Goal 3) and contribute to halting land degradation and biodiversity loss (Goal 15).

Efforts to reduce food waste must be attuned to local context, because its causes vary dramatically. A major driver of food waste in lesser developed countries occurs in the postharvest phase and is attributable to poor storage facilities, suggesting that effective outputs are likely to involve improved physical infrastructure ${ }^{79}$. In developed countries, however, roughly half of food losses occur much later in the value chain, at the consumption phase. Successful efforts in these countries are more likely to revolve around interventions such as changing societal norms and expectations regarding the appearance, provenance and consumption of food. Organizations strive to change societal norms all the time. They call it marketing, and are very good at it ${ }^{80,81}$. Norm transformation can have profound effects, giving rise to "new ways of seeing", which can lead to profound systemic change ${ }^{66}$. New norms around the consumption of food can then be leveraged to other forms of consumption, or engagement with sustainability more broadly.

\section{An experimenting society}

Needless to say, sustainability's complexity implies that many initiatives that employ sound logic models will inevitably fall short of creating meaningful impact. Given this likely outcome, it is worth remembering that a logic model is analogous to a hypothesis: if a program is implemented, then certain results are expected to follow ${ }^{72}$. This is important because hypotheses are routinely falsified, and not all experiments yield expected results, but the failure of specific experiments is part and parcel of the scientific enterprise, and defines its uneven progress. Of course, experiments in real world change are not identical to controlled experiments conducted in labs. Yet, a more expansive definition of experimentation, which views managerial initiatives as activities conducted with an "intent to learn", is a powerful idea in both the social ${ }^{82}$ and ecosystem management ${ }^{22,83}$ literatures. Fully embracing experimentation calls upon us to truly appreciate that sustainability concerns are wicked, and that failures are in fact a good measure of effort and ambition. An "experimenting society" 82 acknowledges that experimentation should be 
evolutionary, and that from a probabilistic perspective, more variation and selection increases the likelihood that beneficial paths will be created. It recognizes that we cannot plot a direct course to sustainability and manage our way to that goal in the most efficient manner possible, because such a course is at odds with how social systems function. A policy promoting ambitious experimentation will in some regards be similar to the venturing model that provides resources to an array of entrepreneurial organizations in high-tech. This resilient model recognizes the difficulty of identifying winners when uncertainty prevails. It does not discountenance failure, and at the same time emphasizes learning and adaptation ${ }^{84,85}$.

Pursuit of sustainability through robust action is motivated by a belief that "through individual and collective experimentation ... humans can learn to navigate their environments skillfully" 86 . Sustainability problems are daunting because they are complex, interpretive and multifaceted. Yet, at the very same time, complex, interpretive and multifaceted problems provide a multitude of entry points for tackling them, making them particularly suited to experimentation, at all levels of scale and effort. A compendium of plausible experiments is Paul Hawken's 2017 book Drawdown ${ }^{87}$, which set forth 100 solutions to global warming, based on peer-reviewed science. Their appeal lies in their systemic nature, all encompassing social, political and technological components. They are also remarkably diverse; among the top 10 are educating girls, reducing food waste and rooftop solar. Each of the 100 solutions is in effect both a business opportunity and a grand challenge ${ }^{88,89}$. Transforming them into reality entails experimenting with emergent ideas, the harnessing of diverse participants in robust action, and thoughtful scaling. A more worthy application of management theory is hard to envision. 
Correspondence should be addressed to Dror Etzion at dror.etzion@mcgill.ca.

\section{Acknowledgements}

McGill's Centre for Strategy Studies in Organizations (CSSO) supported this research. I thank E.

Bennett, A. Gonzalez, A. Li., H. McShane, D. Pencheon for valuable suggestions and feedback.

\section{Competing interests}

The author declares no competing interests. 
Figure 1a - Stylized logic model

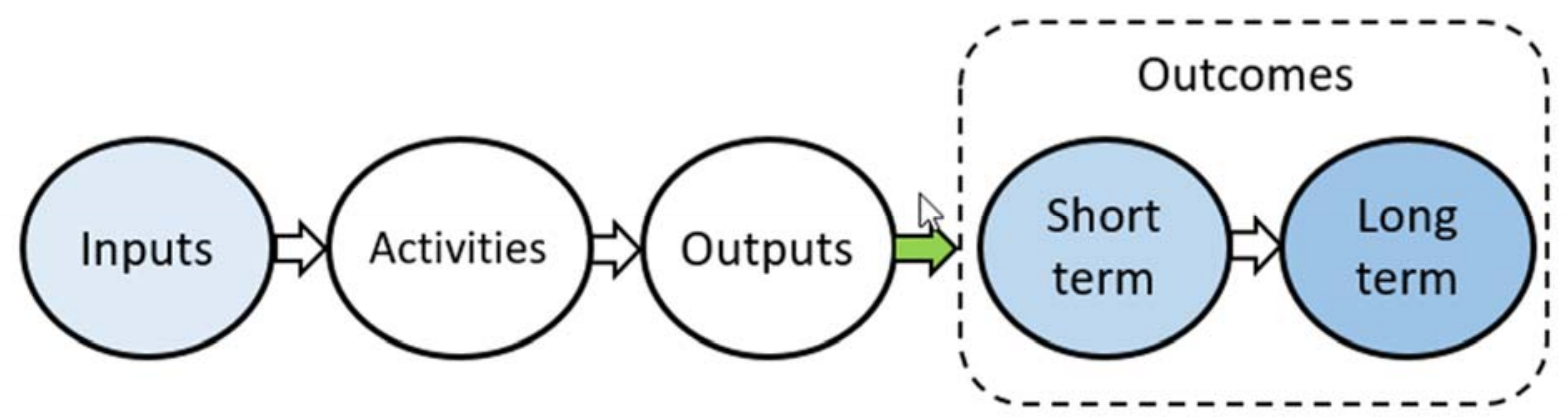

Figure 1b - Logic model for habitat preservation in Indonesia

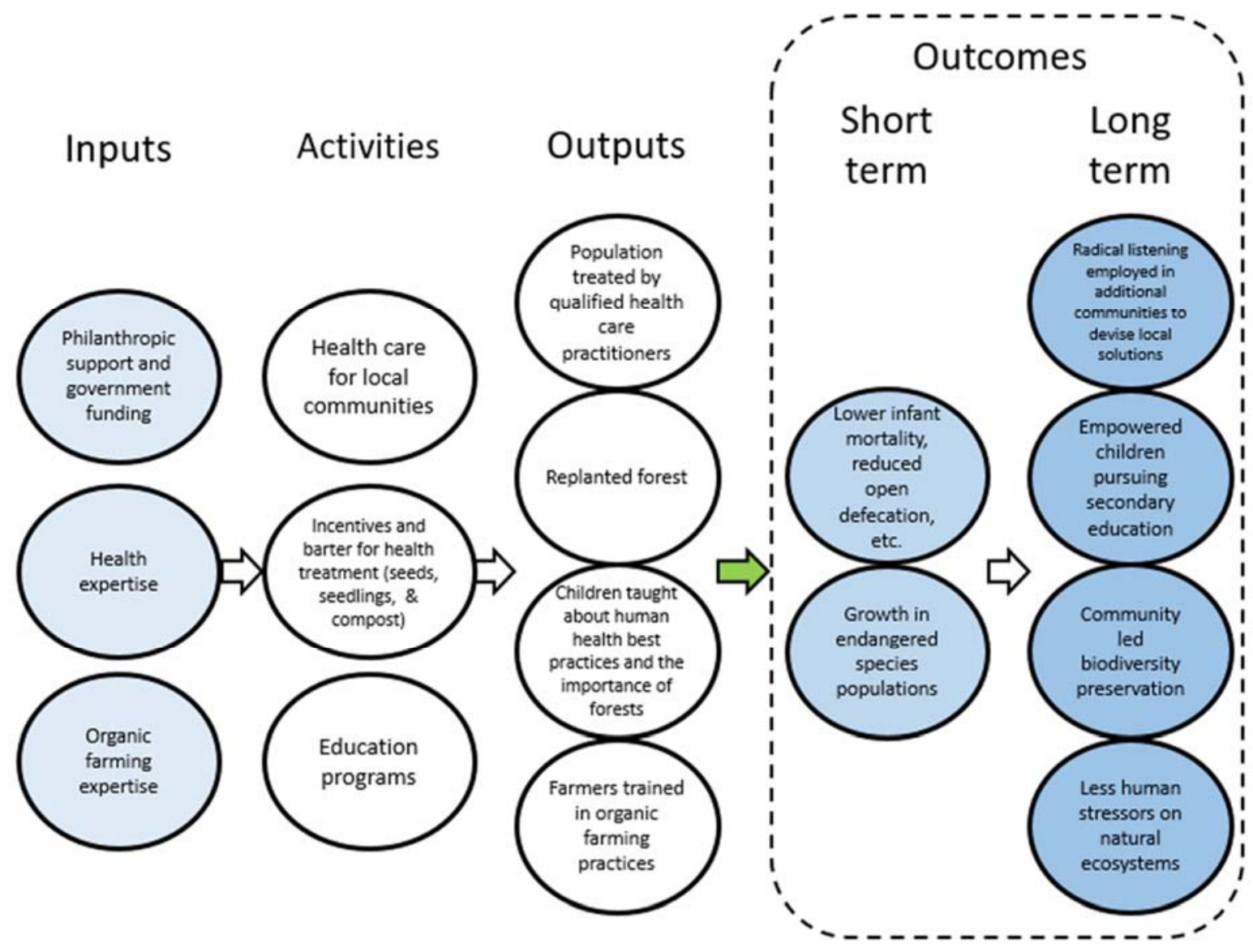

Darker shading indicates increasingly diffuse organizational control and influence. The green arrow indicates where leverage points should be sought. Figure $1 \mathrm{~b}$ adapted from Salisbury $(2017)^{67}$. 
Table 1 - Linking the 17 Sustainable Development Goals

\begin{tabular}{|c|c|c|}
\hline Initiative & Goal & URL \\
\hline SDG Compass & $\begin{array}{l}\text { To provide guidance for companies } \\
\text { on how they can align their strategies } \\
\text { as well as measure and manage their } \\
\text { contribution to the realization of the } \\
\text { SDGs }\end{array}$ & sdgcompass.org \\
\hline $\begin{array}{l}\text { Sustainable Development } \\
\text { Goals: Interlinkages and } \\
\text { Indicators }\end{array}$ & $\begin{array}{l}\text { To support policy integration for } \\
\text { SDG implementation and monitoring } \\
\text { by providing a practical tool on the } \\
\text { analysis of the interlinkages between } \\
\text { SDG targets }\end{array}$ & sdginterlinkages.iges.jp \\
\hline $\begin{array}{l}\text { Global Opportunity } \\
\text { Explorer }\end{array}$ & $\begin{array}{l}\text { To help business leaders, } \\
\text { entrepreneurs and investors connect } \\
\text { with new partners, projects and } \\
\text { markets to foster more partnerships } \\
\text { for the SDGs and a greener and fairer } \\
\text { world by } 2030 \text {. }\end{array}$ & $\begin{array}{l}\text { Www.globalopportunity } \\
\text { explorer.org }\end{array}$ \\
\hline $\begin{array}{l}\text { Better Business, Better } \\
\text { World }\end{array}$ & $\begin{array}{l}\text { To bring together leaders from } \\
\text { business, finance, civil society, } \\
\text { labour, and international } \\
\text { organisations to map the economic } \\
\text { opportunities available to business if } \\
\text { the SDGs are achieved. }\end{array}$ & $\begin{array}{l}\text { www.businesscommissi } \\
\text { on.org }\end{array}$ \\
\hline $\begin{array}{l}\text { SDG Interactions: from } \\
\text { Science to } \\
\text { Implementation }\end{array}$ & $\begin{array}{l}\text { To identify the interactions between } \\
\text { the various goals and targets, } \\
\text { determining to what extent they } \\
\text { reinforce or conflict with each other. }\end{array}$ & $\begin{array}{l}\text { www.icsu.org/publicati } \\
\text { ons/a-guide-to-sdg- } \\
\text { interactions-from- } \\
\text { science-to- } \\
\text { implementation }\end{array}$ \\
\hline
\end{tabular}




\section{References}

1 Strike, V. M., Gao, J. \& Bansal, P. Being Good while Being Bad: Social Responsibility and the International Diversification of US Firms. J. Int. Bus Stud. 37, 850-862 (2006).

2 Banerjee, S. B. Corporate Social Responsibility: The Good, the Bad and the Ugly. Crit. Soc. 34, 51-79 (2008).

3 van Houten, F. in McKinsey Quarterly (2014).

4 Stephens, J. C., Frumhoff, P. C. \& Yona, L. The role of college and university faculty in the fossil fuel divestment movement. Elem. Sci. Anth. 6 (2018).

5 Boudet, H. et al. Effects of a behaviour change intervention for Girl Scouts on child and parent energy-saving behaviours. Nature Energy 1, 16091, doi:10.1038/nenergy.2016.91 (2016).

6 Hatch, M. J. Organization theory: Modern, symbolic, and postmodern perspectives. (Oxford University Press, 2018).

7 Scott, W. R. \& Davis, G. F. Organizations and organizing: Rational, natural and open systems perspectives. (Routledge, 2015).

8 Tsoukas, H. \& Knudsen, C. The Oxford handbook of organization theory. (Oxford University Press, 2003).

9 Shenhav, Y. A. Manufacturing rationality: The engineering foundations of the managerial revolution. (Oxford University Press, 2002).

10 Davis, G. F. Do Theories of Organizations Progress? Org. Res. Meth. 13, 690-709 (2010).

11 Morgan, G. Images of Organization. (Sage, 1986).

12 Scott, W. R. Institutions and Organizations. (Sage, 1995).

13 March, J. G. \& Simon, H. A. Organizations. (Wiley, 1958).

14 Argyris, C. \& Schon, D. A. Theory in practice: Increasing professional effectiveness. (Jossey-Bass, 1974).

15 Hannan, M. T. \& Freeman, J. The Population Ecology of Organizations. Am. J. Soc. 82, 929-964 (1977).

16 Pfeffer, J. \& Salancik, G. The External Control of Organizations. (Harper \& Row, 1978).

17 Etzion, D. Research on Organizations and the Natural Environment, 1992 - Present: A Review. J. of Management 33, 637-664 (2007).

18 Bansal, P., Kim, A. \& Wood, M. O. Hidden in Plain Sight: The Importance of Scale in Organizations' Attention to Issues. Acad. Man. Rev. 43, 217-241 (2018).

19 Williamson, O. E. Comparative Economic Organization: The Analysis of Discrete Structural Alternatives. Admin. Sci. Q. 36, 269-296 (1991).

20 Ostrom, E. Governing the Commons: The Evolution of Institutions for Collective Action. (Cambridge University Press, 1990).

21 Folke, C., Hahn, T., Olsson, P. \& Norberg, J. Adaptive governance of social-ecological systems. Ann. Rev. of Env. Res. 30, 441-473 (2005).

22 Berkes, F. Evolution of co-management: role of knowledge generation, bridging organizations and social learning. J. Env. Man 90, 1692-1702 (2009). 
23 Stankey, G. H., Clark, R. N. \& Bormann, B. T. Adaptive management of natural resources: Theory, concepts, and management institutions. USDA General Technical Report . PNW-GTR-654 (2005).

24 Rist, L., Felton, A., Samuelsson, L., Sandström, C. \& Rosvall, O. A new paradigm for adaptive management. Ecol. and Soc. 18 (2013).

25 Edmondson, A. C. Wicked Problem Solvers. Harvard Bus. Rev. 94, 52-59 (2016).

26 DeFries, R. \& Nagendra, H. Ecosystem management as a wicked problem. Science 356, 265-270 (2017).

27 Rittel, H. W. J. \& Webber, M. M. Dilemmas in a General Theory of Planning. Policy Sciences 4, 155-169 (1973).

28 Verweij, M. et al. Clumsy solutions for a complex world: The case of climate change. Public Admin. 84, 817-843 (2006).

29 Checkland, P. Soft systems methodology: a thirty year retrospective. Sys. Res. \& Behav. Sci. 17, S11 (2000).

30 Checkland, P. Systems thinking, systems practice. (John Wiley \& Sons, 1981).

31 Weick, K. E., Sutcliffe, K. M. \& Obstfeld, D. Organizing and the Process of Sensemaking. Org. Sci. 16, 409-421 (2005).

32 Daft, R. L. \& Weick, K. E. Toward a Model of Organizations as Interpretation Systems. Acad. Man. Rev. 9, 284-295 (1984).

33 Simon, H. A. Administrative Behavior. (Macmillan, 1947).

34 Vaughan, D. The Challenger launch decision: Risky technology, culture, and deviance at NASA. (University of Chicago Press, 1997).

35 Holling, C. S. \& Meffe, G. K. Command and control and the pathology of natural resource management. Cons. Biol. 10, 328-337 (1996).

36 Martin, R. L. The big lie of strategic planning. Harvard Bus. Rev. 92, 3-8 (2014).

37 Mintzberg, H. \& Waters, J. A. Of Strategies, Deliberate and Emergent. Strat. Man. J. 6, 257-272 (1985).

38 Mintzberg, H. Crafting Strategy. Harvard Bus. Rev. 65, 66-75 (1987).

39 Plowman, D. A. et al. Radical Change Accidentally: The Emergence and Amplification of Small Change. Acad. Man. J. 50, 515-543 (2007).

40 Garud, R. \& Karnøe, P. Bricolage versus Breakthrough: Distributed and Embedded Agency in Technology Entrepreneurship. Research Policy 32, 277-300 (2003).

41 Karnøe, P. \& Garud, R. Path creation: Co-creation of heterogeneous resources in the emergence of the Danish wind turbine cluster. Eur. Plan. Stud. 20, 733-752 (2012).

42 Sabel, C. F. \& Victor, D. G. Governing global problems under uncertainty: Making bottom-up climate policy work. Climatic Change, 1-13 (2015).

43 Holling, C. S. Resilience and stability of ecological systems. Ann. Rev. of Eco. \& Sys. 4, 1-23 (1973).

44 Biggs, R. et al. Toward principles for enhancing the resilience of ecosystem services. Ann. Rev. of Env. Res 37, 421-448 (2012).

45 Stouten, J., Rousseau, D. M. \& De Cremer, D. Successful Organizational Change: Integrating the Management Practice and Scholarly Literatures. Acad. Man. Ann. (2018). 
46 Broman, G. I. \& Robèrt, K.-H. A framework for strategic sustainable development. J. Clean. Prod. 140, 17-31 (2017).

47 Pidgeon, N. \& Fischhoff, B. The role of social and decision sciences in communicating uncertain climate risks. Nature Climate Change 1, 35 (2011).

48 Nisbet, E. C., Cooper, K. E. \& Garrett, R. K. The partisan brain: How dissonant science messages lead conservatives and liberals to (dis) trust science. Ann. Amer. Acad. Poli. \& Soc. Sci. 658, 36-66 (2015).

49 Kahan, D. M. et al. The polarizing impact of science literacy and numeracy on perceived climate change risks. Nature Climate Change 2, 732 (2012).

50 Kay, J. Obliquity: Why our goals are best achieved indirectly. (Profile Books, 2011).

51 Eccles, R. G. \& Nohria, N. Beyond the hype: Rediscovering the essence of management. (Beard Books, 1992).

52 Ferraro, F., Etzion, D. \& Gehman, J. Tackling Grand Challenges Pragmatically: Robust Action Revisited. Org. Stud. 36, 363-390 (2015).

53 Padgett, J. F. \& Ansell, C. K. Robust Action and the Rise of the Medici, 1400-1434. Am. J. Soc. 98, 1259-1319 (1993).

54 Whittier, N. Rethinking Coalitions: Anti-Pornography Feminists, Conservatives, and Relationships between Collaborative Adversarial Movements. Soc. Prob. 61, 175-193 (2014).

55 Gillis, J. \& Popovich, N. New York Times (June 6, 2017).

56 Costello, C., Gaines, S. \& Gerber, L. R. Conservation science: A market approach to saving the whales. Nature 481, 139 (2012).

57 Pinch, T. J. \& Bijker, W. E. The Social Construction of Facts and Artefacts: or How the Sociology of Science and the Sociology of Technology might Benefit Each Other. Soc. Stud. Sci. 14, 399-441 (1984).

58 Seelos, C. \& Mair, J. Profitable business models and market creation in the context of deep poverty: A strategic view. Acad. Man. Persp. 21, 49-63 (2007).

59 Duke, D. Why Don't BOP Ventures Solve the Environmental Problems They Initially Set Out to Address? Org. \& Env. 29, 508-528 (2016).

60 Ehrenstein, V. \& Neyland, D. On scale work: Evidential practices and global health interventions. Econ. \& Soc. 47, 59-82 (2018).

61 Gonzalez-Vega, C. \& Villafani-Ibarnegaray, M. in The Handbook of Microfinance (eds Beatriz Armendáriz \& Marc Labie) 203-250 (World Scientific, 2011).

62 Yunus, M., Moingeon, B. \& Lehmann-Ortega, L. Building Social Business Models: Lessons from the Grameen Experience. Long Range Plan. 43, 308-325 (2010).

63 Mintzberg, H. The structuring of organizations: A synthesis of the research. (PrenticeHall, 1979).

64 Prahalad, C. K. \& Hamel, G. The core competence of the corporation. Harvard Bus. Rev. 68, 79-91 (1990).

65 Porter, M. E. From Competitive Advantage to Corporate Strategy. Harvard Bus. Rev. 65, 43-59 (1987).

66 Meadows, D. H. Places to Intervene in a System Whole Earth 91, 78-84 (1997). 
67 Salisbury, C. Paying for health care with trees: A win-win for orangutans and communities. Pacific Standard (2017). $<$ https://psmag.com/news/paying-for-health-carewith-trees-a-win-win-for-orangutans-and-communities $>$.

68 Mair, J., Wolf, M. \& Seelos, C. Scaffolding: A process of transforming patterns of inequality in small-scale societies. Acad. Man. J. 59, 2021-2044 (2016).

69 Poister, T. H. Measuring performance in public and nonprofit organizations. (JosseyBass, 2003).

70 UN-Water Decade Programme on Advocacy and Communication (UNW-DPAC). The water for life decade 2005-2015 and beyond. (2015).

71 Uvin, P., Jain, P. S. \& Brown, L. D. Think large and act small: Toward a new paradigm for NGO scaling up. World Dev. 28, 1409-1419 (2000).

72 McLaughlin, J. A. \& Jordan, G. B. in Handbook of Practical Program Evaluation (eds Joseph S. Wholey, Harry P. Hatry, \& Kathryn E. Newcomer) 55-80 (2010).

73 Rogers, P. J. Using programme theory to evaluate complicated and complex aspects of interventions. Evaluation 14, 29-48 (2008).

74 Weitz, N., Carlsen, H., Nilsson, M. \& Skånberg, K. Towards systemic and contextual priority setting for implementing the 2030 Agenda. Sust. Sci. 13, 531-548 (2018).

75 Le Blanc, D. Towards integration at last? The sustainable development goals as a network of targets. Sust. Dev. 23, 176-187 (2015).

76 United Nations. Transforming our world: The 2030 agenda for sustainable development. (2015).

77 FAO. Food wastage footprint: Full cost accounting. (Food and Agriculture Organization of the United Nations, 2014).

78 Weitz, N., Nilsson, M. \& Davis, M. A nexus approach to the post-2015 agenda:

Formulating integrated water, energy, and food SDGs. SAIS Rev. Int. Aff. 34, 37-50 (2014).

79 Gustavsson, J., Cederberg, C. \& Sonesson, U. Global Food Losses and Food Waste. (Food and Agriculture Organization of the United Nations, 2011).

80 Wilkie, W. L. \& Moore, E. S. Marketing's contributions to society. J. of Marketing 63, 198-218 (1999).

81 Ewen, S. Captains of Consciousness: Advertising and the Social Roots of the Consumer Culture. (McGraw-Hill, 1976).

82 Ansell, C. \& Bartenberger, M. in New Perspectives on Technology in Society:

Experimentation Beyond the Laboratory (eds Ibo van de Poel, Lotte Asveld, \& Donna C. Mehos) 36-58 (Routledge, 2017).

83 Rist, L., Campbell, B. M. \& Frost, P. Adaptive management: Where are we now? Env. Cons. 40, 5-18 (2013).

84 Gordon, A., Becerra, L. \& Fressoli, M. Potentialities and constraints in the relation between social innovation and public policies: some lessons from South America. Ecol. \& Soc. 22 (2017).

85 Kemp, R. The Dutch energy transition approach. Int. Econ. \& Econ. Pol. 7, 291-316 (2010). 
86 Gross, N. Pragmatism and the study of large-scale social phenomena. Theory \& Soc. 47, 87-111 (2018).

87 Hawken, P. Drawdown: The most comprehensive plan ever proposed to reverse global warming. (Penguin, 2017).

88 George, G., Howard-Grenville, J., Joshi, A. \& Tihanyi, L. Understanding and tackling societal grand challenges through management research. Acad. Man. J. 59, 1880 (2016).

89 Reid, W. V. et al. Earth system science for global sustainability: grand challenges. Science 330, 916-917 (2010). 